\title{
KONSEKUENSI HUKUM PEMBATALAN PERKAWINAN MENURUT HUKUM ISLAM
}

\author{
Oleh. Ahmad Supandi Patampari \\ Indonesian Research Corner (IRC), Indonesia \\ Jl. Sungai Musi Kel. Ta’ Kec. Tanete Riattang Kab. Bone, Sul-Sel \\ Email: supandiahmad900522@gmail.com
}

\section{Article history:}

Received: $21-07-2020 \quad$ Revised: $10-08-2020 \quad$ Accepted: 16-08-2020

\begin{abstract}
This article discusses the issue of annulment of marriage according to Islamic law. This is important, onsidering that a marriage should not be annulled, because ideally a marriage aims to form a happy and eternal family, as mandated by the law, at the same time as worship as described in Islam. This article uses a qualitative research method, with a normative juridical approach.

The results of the research reveal that the incident of marriage cancellation according to Islamic law is caused by things that invalidate marriage aqad, such as the prohibition of marriage (mahram) or because of things that have just happened after marriage, such as an apostate party. However, the cancellation of the marriage does not mean that the problem has been resolved. Several new problems arise as a result of the legal consequences of the cancellation of the marriage, such as child problems, joint property issues and problems with interested third parties.
\end{abstract}

Keywords: Annulment of Marriage; Islamic Law; Legal Consequence.

\section{Abstrak}

Artikel ini membahas permasalahan pembatalan perkawinan menurut hukum Islam. Hal ini penting, mengingat tidak seharusnya suatu perkawinan itu dibatalkan, karena idealnya suatu perkawinan bertujuan untuk membentuk keluarga yang bahagia dan kekal, sebagaimana amanah Undang-undang, sekaligus sebagai ladang ibadah sebagaimana yang dikehendaki dalam agama Islam. Artikel ini menggunakan metode penelitian kualitatif, dengan pendekatan yuridis normatif.

Adapun hasil penelitian diungkapkan bahwa peristiwa pembatalan perkawinan menurut hukum Islam, disebabkan karena hal-hal yang membatalkan aqad nikah, seperti larangan kawin (mahram) atau karena hal yang baru terjadi setelah aqad nikah, seperti salah satu pihak murtad. Namun demikian, dengan pembatalan perkawinan tersebut bukan berarti permasalahan telah selesai. Beberapa permasalahan baru muncul sebagai akibat hukum dari pembatalan perkawinan tersebut, seperti masalah anak, masalah harta bersama dan masalah terhadap pihak ketiga yang berkepentingan.

\section{Kata kunci : Hukum Islam; Konsekuensi Hukum; Pembatalan Perkawinan.}


Konsekuensi Hukum Pembatalan Perkawinan... | Ahmad Supandi P.

\section{A. Pendahuluan}

Salah satu ajaran yang penting dalam Islam adalah pernikahan. Begitu pentingnya ajaran tentang pernikahan tersebut, sehingga di dalam al-Qur'an terdapat sejumlah ayat, baik secara langsung maupun tidak langsung berbicara mengenai masalah pernikahan. ${ }^{1}$ Tujuan perkawinan menurut Islam adalah menuruti perintah Allah swt. untuk memperoleh keturunan yang sah dalam masyarakat, dengan mendirikan rumah tangga yang damai dan teratur. ${ }^{2}$ Hal ini senada dengan firman Allah swt. dalam Q.S. Ar-Ruum (30) ayat 21:

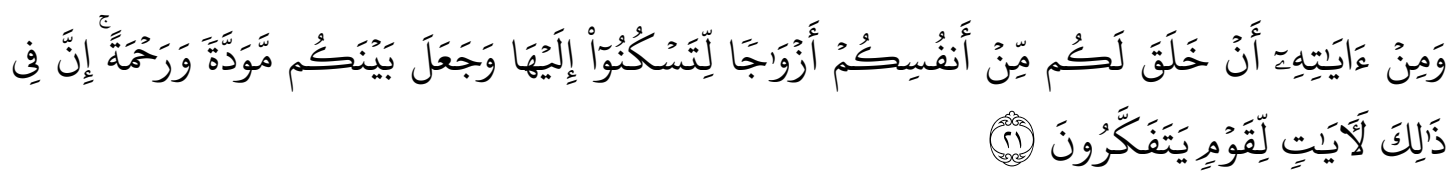

Terjemahnya : Dan di antara tanda-tanda kekuasaan-Nya ialah, Dia menciptakan untukmu isteri-isteri dari jenismu sendiri, supaya kamu cenderung dan merasa tenteram kepadanya, dan dijadikan-Nya diantaramu rasa kasih dan sayang. Sesungguhnya pada yang demikian itu benar-benar terdapat tanda-tanda bagi kaum yang berfikir. ${ }^{3}$

Oleh karena itu, dengan adanya perkawinan dapat mengurangi diri dari perbuatan maksiat dan memelihara diri dari perbuatan zina. Sebagaimana yang dinyatakan dalam hadis yang diriwayatkan oleh Abdullah bin Mas'ud bahwa Rasulullah saw. bersabda yang artinya sebagai berikut: "Wahai kaum muda, barang siapa diantara kalian mampu menyiapkan bekal, nikalah. Karena sesungguhnya menikah dapat menjaga penglihatan dan memelihara farji. Dan barang siapa belum mampu, maka hendaklah ia berpuasa karena puasa dapat menjadi benteng". ${ }^{4}$

Oleh karena itu, sangat relevan apabila Islam mengatur masalah perkawinan dengan teliti dan terperinci, untuk membawa umat manusia hidup dalam kehormatan,

${ }^{1}$ Muhammad Fuad Abd al- Baqi, al- Mu'jam al- Mufahras li al-Faz al-Quran al- Karim (Beirut: Dar alFikr, 1987), h. 332.

2Slamet Abidin dan Aminuddin, Fiqih Munakahat 1 (Cet.1; Bandung: Pustaka Setia,1999), h. 12.

3Departemen AgamaR.I., Al-Qur'an dan Terjemahan (Surakarta: Media Insani Publishing, 2007), h. 366.

${ }^{4}$ Muslich Maruzi, Koleksi Hadits Sikap dan Pribadi Muslim, (Pustaka Amani: Jakarta, 1995), h. 65. 
sesuai kedudukannya yang amat mulia di tengah-tengah makhluk Allah swt. yang lain. $^{5}$ Bagi umat Islam, perkawinan itu sah apabila dilakukan menurut hukum perkawinan Islam. Suatu aqad perkawinan dipandang sah apabila memenuhi rukun dan syaratnya, sehingga keadaan aqad nikah itu diakui oleh hukum syara' ${ }^{6}$

Perkawinan dalam agama Islam disebut "nikah" ialah suatu aqad atau perjanjian untuk mengikatkan diri antara seorang pria dan wanita guna menghalalkan hubungan kelamin antara kedua belah pihak, dengan dasar sukarela dan keridhoan kedua belah pihak untuk mewujudkan suatu kebahagian hidup berkeluarga yang diliputi rasa kasih sayang dan ketentraman dengan cara-cara yang diridhoi Allah swt. ${ }^{7}$

Tetapi tujuan tersebut terkadang dihalangi oleh keadaan yang tidak terpikirkan sebelumnya, misalnya setelah perkawinan berlangsung, di kemudian hari baru diketahui bahwa diantara mereka terdapat hubungan saudara sesusuan. Sejak diketahuinya hal tersebut maka pernikahan tersebut menjadi batal demi hukum. Demikian pula apabila suami istri semula non muslim, tetiba istri masuk Islam dan suami menolak masuk Islam, maka perkawinan mereka dapat dibatalkan. ${ }^{8}$

Peristiwa pembatalan perkawinan sering ditemui dalam masyarakat, oleh sebab pernikahan dilangsungkan tanpa wali, atau dilaksanakan oleh wali yang tidak berhak, atau sebab lain karena para pihak masih terikat di dalam perkawinan dengan pihak lain. Suatu kenyataan yang sulit diterima oleh suami istri, perkawinan yang telah dilaksanakan ternyata oleh Hakim Pengadilan Agama dinyatakan tidak sah dan ikatan perkawinan itu dinyatakan batal. Namun demikian bahwa dengan pembatalan perkawinan tersebut bukan berarti permasalahan telah selesai. tentunya akan muncul permasalahan baru sebagai konsekuensi hukum dari pembatalan perkawinan tersebut.

\footnotetext{
${ }^{5}$ Ahmad Azhar Basyir, Hukum Perkaninan Islam (Cet. IX; UII Press: Yogyakarta, 1999), h. 1.

${ }^{6}$ Zuhri Hamid, Pokok-pokok Hukum Perkawinan Islam dan Undang Perkawinan di Indonesia (Cet. I; ttp:Bina Cipta, 1978), h.24.

7Soemiyati, Hukum Perkawinan Islam dan Undang-Undang Perkawinan, (Yogyakarta: Liberty, 1986), h. 8.

${ }^{8}$ Ahmad Azhar Basyir, Hukum Perkawinan Islam..., h.86.
} 


\section{B. Metode Penelitian}

Penelitian ini merupakan jenis penelitian hukum normatif, terkait dengan akibat hukum pembatalan perkawinan. Jenis penelitian ini adalah kualitatif yang sifatnya deskriptif dengan memakai pendekatan penelitian yuridis normatif. Selain itu, data dan sumber data dalam penelitian ini bersumber dari kepustakaan dengan memakai teknik pengumpulan data studi dokumen.

Dalam mengelola data yang telah dikumpulkan, penulis menggunakan cara berfikir deduktif, yakni bertolak dari proposisi umum, yang kebenarannya telah diketahui dan berakhir pada suatu kesimpulan yang bersifat khusus (premis minor). Sedangkan analisis teks yang digunakan dalam penelitian ini adalah analisis deskriptif kualitatif. Penelaan sinkronisasi atas ketentuan hukum Islam tentang pembatalan perkawinan dan dilakukan interprestasi hukum positif.

\section{Pembahasan}

\section{Konsep Pembatalan Perkawinan Menurut Hukum Islam}

Dalam hukum Islam hanya dikenal perkawinan yang sah dan tidak sah. Perkawinan yang tidak sah dianggap perkawinan itu tidak pernah ada, sedangkan yang sah hanya mungkin putus karena kematian, talak, khulu' pelanggaran taklik talak, dan fasakh. Istilah fasakh secara bahasa, menurut pendapat Ibnu Mundzir dalam Lisanul 'arab menyatakan pembatalan perkawinan dengan istilah fasakh yang berarti batal (نقذ) atau bubar (فرق).

Sedang secara istilah pembatalan perkawinan atau fasakh adalah lepas atau batalnya ikatan perkawinan antara suami dan istri, adakalanya disebabkan hal-hal yang mendatang yang menyebabkan aqad nikah tersebut tidak dapat dilanjutkan. Pembatalan perkawinan adalah pembatalan hubungan suami istri sesudah dilangsungkan aqad nikah. ${ }^{10}$

\footnotetext{
${ }^{9}$ Muhammad Baqir Al-Habsyi, Fiqh Praktis (Menurut al-Qur'an, As-Sunnah dan pendapat para Ulama) (Bandung: Mizan, 2002), h. 218.

${ }^{10}$ Ali Zainuddin, Hukum Perdata Islam Di Indonesia, (Jakarta: Sinar Grafika, 2007), h. 37.
} 
Di dalam fikih sebenarnya dikenal dua istilah yang berbeda kendati hukumnya sama yaitu nikah al-fasid dan nikah al-batil. Al-Jaziry menyatakan bahwa nikah fasid adalah nikah yang tidak memenuhi salah satu syarat dari syarat-syaratnya, sedangkan nikah al-batil adalah apabila tidak terpenuhinya rukun. Hukum nikah fasid dan batil adalah tidak sah. Dalam terminologi UU Perkawinan, baik nikah fasid dan maupun nikah batil dapat digunakan untuk pembatalan dan bukan pada pencegahan. ${ }^{11}$

Dalam Bab VI pasal 37 Peraturan Pemerintah No. 9 Tahun 1975 tentang pelaksanaan UU No. 1 Tahun 1974 disebutkan bahwa "Batalnya suatu perkawinan hanya dapat diputuskan oleh pengadilan". ${ }^{12}$ Dalam pasal tersebut dapat dimengerti bahwa pengertian pembatalan perkawinan adalah perkawinan yang batal karena sebab-sebab tertentu yang pembatalannya harus diajukan ke pengadilan dan harus melalui keputusan Pengadilan.

Sedangkan pada UU No. 1 Tahun 1974 Tentang Perkawinan Pasal 22 dinyatakan dengan tegas bahwa perkawinan dapat dibatalkan, apabila para pihak tidak memenuhi syarat-syarat untuk melangsungkan perkawinan. Di dalam penjelasannya kata "dapat" dalam pasal ini bisa diartikan bisa batal atau bisa tidak batal, bilamana menurut ketentuan agama masing-masing tidak menentukan lain. Perkawinan dapat dibatalkan berarti sebelumnya telah terjadi perkawinan lalu dibatalkan karena adanya pelanggaran terhadap aturan-aturan tertentu. ${ }^{13}$

Di dalam Kompilasi Hukum Islam (KHI) juga tidak diberikan secara rinci mengenai pembatalan perkawinan, akan tetapi dari penjelasan-penjelasan yang terdapat dalam Bab XI pasal $70 \mathrm{KHI}$, dapat disimpulkan bahwa pembatalan perkawinan adalah batalnya suatu perkawinan yang penyebab batalnya baru diketahui atau baru terjadi setelah perkawinan tersebut sah diakui menurut hukum agama Islam maupun oleh hukum Negara Indonesia.

\footnotetext{
${ }^{11}$ Martiman P., HukumPerkawinan Indonesia, (Jakarta: Center Publishing, 2002), h. 25.

${ }^{12}$ Dirjen Bimas Islam dan Penyelenggaraan Haji, Departemen Agama RI, Himpunan Peraturan Perundang-Undangan RI (Jakarta: Direktorat Urusan Agama Islam, 2002), h. 97.

${ }^{13}$ Martiman P., HukumPerkawinan Indonesia..., h. 25.
} 


\section{Sebab-Sebab Pembatalan Perkawinan}

Dalam hukum Islam pembatalan perkawinan dapat terjadi karena dua hal, yaitu: pertama, terdapat hal-hal yang membatalkan aqad nikah yang dilaksanakan. Para imam madzhab yakni, Imam Malik, Syafi'i, Hanafi dan Hanbali, sepakat bahwa jika terjadi perkawinan dengan perempuan (mahram) yang disebut dalam al-Qur'an, maka hukumnya adalah haram dan perkawinan itu harus difasakh, ${ }^{14}$ dan menunjukkan larangan abadi untuk orang-orang yang dinikahi, Maka ketika hal-hal tersebut diketahui, aqad tersebut dinyatakan rusak seketika itu juga tanpa memerlukan adanya keputusan pengadilan. ${ }^{15}$

Kedua, terdapat hal baru yang dialami sesudah aqad nikah terjadi dan hubungan perkawinan sementara berlangsung. Seperti dalam hal perkawinan dilakukan dengan modus penipuan, yakni suami yang semula beragama non Islam kemudian masuk Islam hanya untuk menikahi wanita Muslimah (secara formalitas), dan setelah pernikahan terjadi suami kembali pada agama semula, maka perkawinan yang demikian dapat dilakukan pembatalan. Para Imam Madzhab menambahkan beberapa alasan yang menjadi bolehnya pembatalan perkawinan tersebut diantaranya:

Dalam madzhab Hanafi dan Maliki memperbolehkan pembatalan perkawinan dengan sebab: karena murtadnya kedua suami istri tersebut; perceraian disebabkan rusaknya perkawinan itu; bubar dikarenakan tiadanya kesamaan status $(k u f u) .{ }^{16}$ Begitu juga dalam madzhab Syafi'i dan Hambali memperbolehkan pembatalan perkawinan dengan tambahan sebab: karena cacatnya seseorang dari pasangan tersebut; disebabkan berbagai kesulitan suami (I'sar); dan tiada kesamaan status atau (tidak sekufu). ${ }^{17}$

\footnotetext{
${ }^{14}$ M.Rifa'I, Terjemah Khulashah Kifayatul Abyar (Semarang, CV.Toha Putra, T'Th), h. 307.

${ }^{15}$ M. Anwar, Dasar-dasar Hukum Islam dalam Menetapkan Keputusan di Pengadilan Agama (Bandung: CV.Diponegoro, 1991), h. 73.

${ }^{16}$ Abdullah Nashih Ulwan, Adab al-Khitbah wa al-Zafaf (Etika Memilih Jodoh) Terj. Abdul Halim Hamid, (Jakarta: Cahaya Press, TTh), h. 72.

${ }^{17}$ M.Anwar, Dasar-dasar Hukum Islam..., h. 79.
} 
Vol. 2; No. 2;

Desember 2020

Menurut Kompilasi Hukum Islam di dalam Bab XI Pasal 70 perkawinan dinyatakan batal (batal demi hukum) apabila: Suami melakukan perkawinan, sedang ia tidak berhak melakukan aqad nikah karena sudah mempunyai empat orang istri, sekalipun salah satu dari keempat istrinya itu dalam masa iddah talak raj' $i$; Seseorang menikahi bekas istrinya yang telah dili'annya; Seseorang menikahi bekas istri yang pernah dijatuhi tiga kali talak olehnya, kecuali bila bekas istri tersebut pernah menikah lagi dengan pria lain kemudian bercerai lagi $\mathrm{Ba}$ ' $\mathrm{da}$ dukhul dari pria tersebut dan telah habis masa iddah; Perkawinan dilakukan antara dua orang yang mempunyai hubungan darah; semenda dan sesusuan sampai derajat tertentu yang menghalangi perkawinan menurut pasal 8 UU No 1 tahun $1974 .{ }^{18}$

Di dalam UU perkawinan No 1 Tahun 1974 pasal 22, pasal 24, pasal 26 dan pasal 27, dijelaskan sebab-sebab/ alasan-alasan dibatalkannya suatu perkawinan yaitu sebagai berikut: pasal 22 "Perkawinan dapat dibatalkan, apabila para pihak tidak memenuhi syarat-syarat untuk melangsungkan perkawinan”. Dan, Pasal 24 "Barangsiapa karena perkawinan masih terikat dirinya dengan salah satu dari kedua belah pihak dan atas dasar masih adanya perkawinan dapat mengajukan pembatalan perkawinan yang baru, dengan tidak mengurangi ketentuan pasal 3 ayat (2) dan pasal 4 UU ini". Serta, Pasal 26 "Perkawinan yang dilangsungkan dimuka pencatat perkawinan tidak berwenang, wali nikah yang tdak sah atau yang dilangsungkan tanpa dihadiri oleh 2 (dua) orang saksi, dapat dimintakan pembatalannya oleh para keluarga garis keturunan lurus ke atas, jaksa dan suami atau istri”. Diperjelas dalam Pasal 27 ayat (1) "Seorang suami istri dapat mengajukan permohonan pembatalan perkawinan apabila perkawinan dilangsungkan dibawah ancaman yang melanggar hukum." Dan ayat (2) "Seorang dapat mengajukan permohonan pembatalan perkawinan apabila pada waktu berlangsungnya perkawinan terjadi salah sangka mengenai diri suami atau istri."19

${ }^{18}$ Departemen Agama R.I., Kompilasi Hukum Islam Di Indonesia (Jakarta: Direktur Pembinaan Badan Peradilan Agama Islam, 1999) h. 86.

${ }^{19}$ Dirjen Bimas Islam, Departemen Agama RI, Himpunan Peraturan ..., h. 19. 


\section{Akibat Hukum Pembatalan Perkawinan}

Pembatalan perkawinan sebagai salah satu upaya pemutusan hubungan perkawinan adalah menjadi wewenang dan tanggung jawab badan peradilan, mengingat akibat yang ditimbulkan tidak hanya menyangkut suami istri saja. Gugatan pembatalan perkawinan diajukan ke Pengadilan Agama yang mewilayahi tempat perkawinan itu dahulunya dilangsungkan, atau ke Pengadilan Agama yang mewilayahi tempat tinggal suami istri yang bersangkutan, atau ke Pengadilan Agama yang mewilayahi tempat kediaman salah seorang dari suami istri tersebut. ${ }^{20}$ Batalnya suatu perkawinan dimulai setelah keputusan Pengadilan mempunyai kekuatan hukum tetap dan berlaku sejak saat berlangsungnya perkawinan. Adapun Akibat hukum pembatalan perkawinan, yaitu:

a) Terhadap Anak

Akibat hukum pembatalan perkawinan dalam UU Perkawinan No 1 Tahun 1974 pasal 28 sebagai berikut: Batalnya suatu perkawinan dimulai setelah keputusan pengadilan mempunyai kekuatan hukum yang tetap berlaku sejak berlangsungnya perkawinan; Keputusan tidak berlaku surut terhadap; Anak-anak yang lahir dari perkawinan tersebut; Suami atau istri yang bertindak dengan I'tikad baik, kecuali terhadap harta bersama, bila pembatalan perkawinan didasarkan atas adanya perkawinan lain yang dahulu; Orang-prang ketiga lainnya termasuk a dan b sepanjang mereka memperoleh hak-hak dengan i'tikad baik sebelum keputusan tentang pembatalan mempunyai hukum tetap. $^{21}$

Dalam Pasal 28 ayat (2) Wibowo Reksopradoto memberikan ulasan sebagai berikut: Keputusan tidak berlaku surut terhadap anak-anak yang dilahirkan dari perkawinan tersebut. ${ }^{22}$ Anak-anak yang dilahirkan dalam perkawinan yang telah

\footnotetext{
${ }^{20}$ Roihan A. Rasyid, Hukum Acara Peradilan Agama (Jakarta: PT Raja Grafindo Persada, Jakarta, t.th), h. 52.

${ }^{21}$ Dirjen Bimas Islam, Departemen Agama RI, Himpunan PerturanPerundangan ...t, h. 19.

${ }^{22}$ Wibowo Reksopradoto, Hukum Perkawinan Nasional Jilid II Tentang Batal dan Putusnya Perkawinan (Itikad Baik, Semarang, 1978), h. 25.
} 
dibatalkan tidak berlaku surut, sehingga dengan demikian anak-anak ini dianggap sah, meskipun salah seorang atau kedua orang tuanya beritikad buruk.

Dalam Bab IV bagian ke-VI pasal 95 Kitab UU Hukum Perdata (B.W) menyatakan; "Suatu perkawinan yang kemudian dibatalkan, mempunyai akibat perdata baik terhadap suami istri maupun terhadap anak-anak mereka, asalkan perkawinan itu oleh suami istri kedua-duanya dilakukan dengan i'tikad baik". tetapi jika i'tikad baik itu hanya pada salah satu pihak saja, maka pasal selanjutnya yakni pasal 96 menyatakan bahwa pihak yang berlaku dengan i'tikad baik mendapat akibat perdata yang menguntungkan saja, begitu pula anak-anaknya. Sebaliknya bagi yang beri'tikad buruk, maka pembalatan perkawinan itu mengakibatkan penghukuman untuk membayar segala biaya ganti rugi dan bunga bagi pihak lainnya. ${ }^{23}$

Dalam soal perkawinan, seseorang dianggap beri’tikad baik, jika ia tidak mengetahui larangan yang ditentukan menurut hukum suatu perkawinan sehingga dalam perjalanannya perkawinan itu dibatalkan dikarenakan sebab larangan yang telah dilanggarnya. Hal ini berdasarkan kemanusiaan dan kepentingan anak-anak yang tidak berdosa, patut mendapatkan perlindungan hukum. Dan tidak seharusnya bila anak-anak yang tidak berdosa harus menanggung akibat tidak mempunyai orang tua, hanya karena kesalahan orang tuanya, dengan demikian menurut UU No. 1. Tahun 1974 anak-anak yang dilahirkan itu mempunyai status hukum yang jelas sebagai anak sah dari kedua orang tuanya yang perkawinannya dibatalkan.

b) Terhadap harta yang diperoleh selama perkawinan

Sebelum membicarakan harta kekayaan suami istri dalam perkawinan, terlebih dahulu harus dilihat mengenai kedudukan harta orang Islam secara umum. Dalam bidang harta kekayaan seseorang dan cara penyatuan atau penggabungan harta tersebut dengan harta orang lain dikenal dengan nama syirkah atau syarikah. Dari asal-usulnya harta suami istri itu dapat digolongkan pada tiga golongan. 
Harta masing-masing suami istri yang telah dimilikinya sebelum mereka kawin baik berasal dari warisan, hibah atau usaha mereka sendiri-sendiri atau dapat disebut harta bawaan; Harta masing-masing suami istri yang dimilikinya sesudah mereka berada dalam hubungan perkawinan, tetapi diperolehnya bukan dari usaha mereka baik seorang-seorang atau bersama-sama, tetapi merupakan hibah, wasiat atau warisan untuk masing-masing; Harta yang diperoleh sesudah mereka berada dalam hubungan perkawinan atas usaha mereka berdua atau usaha salah seorang mereka atau disebut harta pencarian. ${ }^{24}$

Di lihat dari sudut hubungan harta dengan perorangan dalam masyarakat, harta itu akan berupa: Harta milik bersama; Harta milik seseorang tetapi terikat kepada keluarga; Harta milik seseorang dan pemilikan dengan tegas oleh yang bersangkutan. Pada dasarnya harta suami dan harta istri terpisah, baik harta bawaannya, atau harta yang diperoleh oleh salah seorang suami istri atas usahanya sendiri-sendiri maupun harta hibah yang diperoleh oleh salah seorang mereka karena hadiah atau hibah atau warisan sesudah mereka terikat dalam hubungan perkawinan.

Walaupun demikian telah dibuka kemungkinan syirkah atas harta kekayaan suami istri itu secara resmi dan menurut cara-cara tertentu. Suami istri dapat mengadakan syirkah atas percampuran harta kekayaan yang diperoleh suami dan/atau istri selama masa adanya perkawinan atas usaha suami atau istri sendiri-sendiri, atau atas usaha mereka bersama-sama. Begitupun mengenai harta kekayaan usaha sendirisendiri, sebelum perkawinan dan harta yang berasal bukan dari usaha salah seorang atau bukan dari usaha mereka berdua, tetapi berasal dari pemberian atau warisan atau lainnya yang khusus untuk mereka masing-masing.

Sedangkan dalam Kompilasi Hukum Islam, menggariskan bahwa pada dasarnya tidak ada percampuran antara harta suami dan harta istri karena perkawinan, adanya harta bersama tidak menutup kemungkinan adanya harta milik masing-masing suami dan istri. Harta istri tetap menjadi hak istri dan dikuasai penuh olehnya,

\footnotetext{
${ }^{24}$ Sayuti Thalib, Hukum Kekeluargaan Indonesia, (Penerbit UI: Jakarta t.th), h.83.
} 
demikian juga harta suami tetap menjadi hak suami dan dikuasai penuh olehnya. Harta bawaan dari masing-masing suami dan istri dan harta yang diperoleh masingmasing sebagai hadiah atau warisan adalah di bawah penguasaan masing-masing, sepanjang para pihak tidak menentukan lain dalam perjanjian perkawinan.

Suami dan istri mempunyai hak sepenuhnya untuk melakukan perbuatan hukum atas harta masing-masing berupa hibah, hadiah, sedekah atau lainnya. Bagi harta kekayaan bersama (gono-gini) merupakan harta bersama yang menjadi milik bersama, hanya saja tidak boleh merugikan pihak yang beritikad baik, bagaimanapun juga pihak yang beritikad baik harus diuntungkan, bahkan bagi pihak yang beritikad buruk harus menanggung segala kerugian-kerugian termasuk bunga-bunga harus ditanggung. Harta-harta kekayaan yang dibawa oleh pihak yang beri'tikad baik tidak boleh dirugikan, sedangkan harta kekayaan yang beri'tikad baik bila ternyata dirugikan, kerugian ini harus ditanggung oleh pihak yang beritikad buruk. Dan segala perjanjian perkawinan yang merugikan pihak yang beri'tikad baik harus dianggap tidak pernah ada.

c) Terhadap Pihak Ketiga

Orang-orang ketiga lainnya tidak termasuk dalam a dan b sepanjang mereka memperoleh hak-hak dengan i'tikad baik sebelum keputusan tentang pembatalan mempunyai kekuatan hukum tetap. Terhadap pihak ketiga yang beri'tikad baik pembatalan perkawinan tidak mempunyai akibat hukum yang berlaku surut, jadi segala perbuatan perdata atau perikatan yang diperbuat suami istri sebelum pembatalan perkawinan tetap berlaku, dan ini harus dilaksanakan oleh suami istri tersebut, sehingga pihak ketiga yang beri'tikad baik tidak dirugikan. ${ }^{25}$

Bagi anak-anak yang orang tuanya telah dibatalkan perkawinannya mereka tetap merupakan anak sah dari ibu dan bapaknya. Oleh karena itu anak-anak tetap menjadi anak sah, maka status kewarganegaraannya, tetap mengikuti warga negara bapaknya, dan akibat perdata lainnya ia mengikuti kedudukan hukum orangtuanya.

${ }^{25}$ Sayuti Thalib, Hukum Kekeluargaan Indonesia..., h.95. 
Konsekuensi Hukum Pembatalan Perkawinan... | Ahmad Supandi P.

\section{Penutup}

Mengacu pada uraian sebelumnya, maka penulis menarik kesimpulan yaitu, sebagai berikut:

1. Pembatalan perkawinan adalah pembatalan hubungan suami istri sesudah dilangsungkan aqad nikah. Dalam BAB VI pasal 37 Peraturan Pemerintah No. 9 Tahun 1975 tentang pelaksanaan UU No. 1 Tahun 1974 disebutkan bahwa "Batalnya suatu perkawinan hanya dapat diputuskan oleh pengadilan Sedangkan pada UU No. 1 Tahun 1974 tentang Perkawinan Pasal 22 dinyatakan dengan tegas bahwa perkawinan dapat dibatalkan, apabila para pihak tidak memenuhi syarat-syarat untuk melangsungkan perkawinan.

2. Dalam hukum Islam pembatalan perkawinan dapat terjadi karena dua hal, yaitu: terdapat hal-hal yang membatalkan aqad nikah yang dilaksanakan; Serta, terdapat hal baru yang dialami sesudah aqad nikah terjadi dan hubungan perkawinan sementara berlangsung.

3. Konsekuensi hukum dari pembatalan perkawinan yaitu: berakibat terhadap anak; terhadap harta yang diperoleh selama perkawinan; terhadap pihak ketiga.

\section{DAFTAR PUSTAKA}

Abd al- Baqi, Muhammad Fuad, al- Mu'jam al-Mufahras li al-Faz al-Quran alKarim, Beirut: Dar al-Fikr, 1987.

A. Rasyid, Roihan, Hukum Acara Peradilan Agama, Jakarta: PT Raja Grafindo Persada, Jakarta. T.th.

Basyir, Ahmad Azhar, Hukum Perkawinan Islam, Cet. IX; UII Press: Yogyakarta, 1999.

Departemen AgamaR.I. Al-Qur'an dan Terjemahan, Surakarta: Media Insani Publishing, 2007.

Direktur Pembinaan Badan Peradilan Agama Islam, Kompilasi Hukum Islam Di Indonesia, Jakarta: 1999. 
Direktorat Jendral Bimbingan Masyarakat Islam dan Penyelenggaraan Haji, Departemen Agama RI, Himpunan Peraturan Perundang-Undangan RI, Jakarta: Direktorat Urusan Agama Islam, 2002.

Ensiklopedia Islam 3;Jakarta: PT. Ichtiar Baru Van Hoeve, 2001.

Hamdani, Risalah An-Nikah, penerjemah Agus Salim, Jakarta: Pustaka Amani, 2002.

Hamid, Zuhri, Pokok-pokok Hukum Perkawinan Islam dan Undang Perkawinan di Indonesia, Cet. I; ttp:Bina Cipta, 1978.

Maruzi, Muslich, Koleksi Hadits Sikap dan Pribadi Muslim, Pustaka Amani: Jakarta, 1995.

Muhammad Baqir Al-Habsyi, Fiqh Praktis (Menurut al-Qur'an, As-Sunnah dan pendapat para Ulama), Bandung: Mizan, 2002.

M. Anwar, Dasar-dasar Hukum Islam dalam Menetapkan Keputusan di Pengadilan Agama,Bandung: CV.Diponegoro, 1991.

M.Rifa'I, Terjemah Khulashah Kifayatul Ahyar, Semarang, CV.Toha Putra, t.th.

Prodjohamidjojo, Martiman, Hukum Perkawinan Indonesia, Jakarta: Indonesia Legal Center Publishing, 2002.

Rasyid H, Sulaiman, Fiqh Islam, Sinar Baru Al-gensindo: Bandung, 2006.

Sayuti Thalib, Hukum Kekeluargaan Indonesia, Penerbit UI, Jakarta t.th.

Slamet Abidin dan Aminuddin, Fiqih Munakahat 1, Cet.1; Bandung: Pustaka Setia, 1999.

Soemiyati, Hukum Perkawinan Islam dan UUPerkawinan, Yogyakarta: Liberty, 1986.

Ulwan, Abdullah Nashih, Adab al-Khitbah wa al-zafaf (etika memilih jodoh), penerjemah Abdul Halim Hamid, Jakarta: Cahaya Press, t.th.

Wibowo Reksopradoto, Hukum Perkawinan Nasional Jilid II Tentang Batal dan Putusnya Perkawinan, Itikad Baik: Semarang, 1978.

Zainuddin,Ali, HukumPerdata Islam Di Indonesia, Jakarta: SinarGrafika, 2007. 